\title{
Від головного редактора
}

\section{Шановний читачу!}

Маю честь представити свіжий доробок авторів «Українського інформаційного простору» - єдиного в Україні наукового журналу 3 чітко окресленою проблематикою з історії, теорії і практики функціонування соціально значущої інформації в суспільно-політичних реаліях нашої держави та у світовому контексті. Редколєгія і творці часопису взяли орієнтир на різнобічне висвітлення теоретичних, практичних та історичних аспектів головних складових українського інформаційного простору: преси, радіо, телебачення, мережевих платформ та книжкових видань.

Хочу привернути увагу на декілька знакових у цьому числі публікацій.

Зазвичай на відкриття чергового числа відбираємо теми 3 актуальних питань національного інформаційного простору, які потребують прискіпливого аналізу дослідником та подальшого обговорення науковим співтовариством.

Новий і перспективний ракурс осмислення соціальних мереж виокремив у своїй статті професор Михайло Поплавський. Це навсправжки вибухове своєю масовістю комунікаційне явище тут розглядається не лише як потужний канал самопрезентації та самоідентифікації своєрідного «Я-Образу», а і як культурно-просвітницький ресурс, дієвий інструмент для виховання студентської молоді, коригування іï ціннісних орієнтацій, розвитку самосвідомості і професійного самовдосконалення. Емпіричним матеріалом для дослідження слугували такі популярні серед молоді майданчики мережевого спілкування як Фейсбук, Інстаграм, Снепчат, Твіттер.

На початок третього тисячоліття українці залишаються єдиною в цивілізованому світі нацією (принаймні на теренах Західної Европи), яка й досі не має повного репертуару книжкових і пресових видань своєю мовою. На кшталт, скажімо, багатотомних видань польської «Polonica» чи естонської «Estonica». Спроба з'ясувати генезу питання та окреслити конкретними штрихами перспективи її розв’язання в такому важливому сегменті національного гуманітарного поля, яким є діаспорне пресо- і книговидання, уперше здійснена в статті М. Тимошика «До проблеми створення першого репертуару книжкових та пресових видань українців на чужині: на матеріалах Великої Британії.

У руслі захисту українського інформаційного простору від нав’язування російських міфів про видатні постаті української історії, конкретно - Ярослава Мудрого, у координатах державотворчих процесів розцінюємо осібну актуальність дослідження авторитетного іс- 
торика-українознавця Ярослава Калакури. Для молодих дослідників це - еталон наукового сумління, небайдужості вченого до спроб північних сусідів у чергове переписати концепцію давнього минулого, ствердити заяложені ідеологеми й міфи. На жаль, подібними міфами і їхніми носіями-авторами все ще переповнені шпальти деяких загальноукраїнських 3МІ та телеканалів.

Розширює й доповнює вище означену тему, але з погляду сучасних реалій, наш постійний автор професор Мар'ян Житарюк зі Львова. Цього разу учений фокусує увагу на сучасному стані й перспективах інформаційно-психологічного протистояння за трикутником «Кремль - Україна - Захід» упродовж воєнної агресії Росії супроти України та Европи, починаючи з 2014 р. Зміст фактологічного ряду склала чорноморська тематика українських і зарубіжних 3МI.

3-поміж інших загроз національному інформаційному простору виділяємо ту, що набирає силу і стає неконтрольованою державними чинниками. Професорка Ірина Фаріон називає цю загрозу явищем англоварваризації й зосереджує зусилля на її генезі в освітньо-науковому середовищі. На думку вченої, циркулювання чужих мов у культурно-політичному просторі України та їхня пріоритетність в освітньо-науковій царині призвела до помітного відставання українських державотворчих процесів, порівнюючи 3 найближчими й дальшими сусідами.

Новим у цьому випуску журналу є розділ «Документи 3 архівів української діаспори». Його поява спонукана задавненою потребою введення до наукового обігу низки журналістикознавчих документів, які творили на чужині безпосередні учасники українського пресового та книговидавничого руху. За умов, коли в держави все ще не доходять руки до оцифровування значного масиву розпорошених у просторі документів із цієї проблематики, а час невмолимо руйнує безцінні з історичного погляду паперові носії, робимо маленьку спробу продовжити життя деяких із документів. Таких, що зовсім невідомі в Україні. Переконані, що це буде цінною поживою для нинішніх і майбутніх дослідників історії української журналістики та видавничої справи.

А презентуємо новий розділ статтею маловідомого сучасникам талановитого публіциста УПА Петра Федуна (Полтави) «Якими повинні бути радіопередачі «Голосу Америки» для Совєтського Союзу». Проблематика цієї статті виглядає досить суголосною із таким же запитанням до багатьох нинішніх керівників і журналістів наших українських радіо- та телеканалів: якими вони насправді мають бути? 